\title{
Combined Geochemical and Mineralogical Investigation of Gold Mineralized Quartz Veins at the Vertigo Target, White Gold District, Yukon, Canada
}

James Alexander ${ }^{1}$, Lisa Van Loon ${ }^{2}$ and Neil Banerjee ${ }^{3}$

${ }^{1}$ Department of Earth Sciences, Western University, United States, ${ }^{2}$ LISA CAN Analytical Solutions Inc., United States, ${ }^{3}$ Western University, United States

Introduction: The Au-mineralized Vertigo target of the JP Ross (JPR) property is located $\sim 70 \mathrm{~km}$ south of Dawson City in the White Gold District, west-central Yukon-Tanana Terrane (YTT). The mid- to latePaleozoic YTT nested arc complex endured at least ten mineralizing pulses during tectonic convergence where vein, structurally controlled, and intrusion-related gold events spanned the Mesozoic-Cenozoic [1]. Gold mineralized showings in the west-central YTT comprise a segment of the Yukon-Tintina Gold Province, which represents a range of deposit types that define a 45-m.y.-long phase of arc magmatism [2]. Multiple mineralized quartz vein showings specifically in the west-central Yukon Territory are oriented along conspicuous E-W horizons and are bound between 2 regional NW-trending dextral faults.

Gold at the Vertigo target is hosted in a series of moderate- to high-angle, E-SE striking, S-SW dipping auriferous quartz veins and fracture sets discordant to bedding. Gold mineralization is associated primarily with quartz +/- galena-arsenopyrite-pyrite +/- arsenates +/- secondary oxides in quartz veins hosted by competent felsic lithologies susceptible to brittle fracturing. Gold-mineralized zones exhibit a strong geochemical correlation with As-Ag-Te-Pb-Bi $+/-\mathrm{Cu}-\mathrm{Co}-\mathrm{Zn}$. The current study is using petrography, electron probe microanalysis (EPMA), micro X-ray fluorescence ( $\mu \mathrm{XRF})$, and synchrotron radiation Xray diffraction (SR-XRD) to interpret the spatial distribution of elements in a mineralogical, textural, and structural context.

Investigation of the geochemical relationships, textures, and sulphides in Au-mineralized samples for least altered, altered, and most altered zones has revealed the primary and secondary Au-mineralizing processes [3]. Gold-mineralized samples taken from least altered zones occur in quartz-carbonate-sulphide veins where $\mathrm{Au}$ resides in Ag-Te inclusions [ 20 $\mu \mathrm{m}]$ in subhedral-euhedral pyrite with associated galenachalcopyrite-magnetite-sphalerite. Gold-mineralized samples gathered from vuggy quartz-sulphide veins in oxidized and altered zones exhibit coarse gold $[>100 \mu \mathrm{m}]$ in subhedral galena-bearing fractures and in quartz vein material. Gold-mineralized samples taken from intensely oxidized vuggy quartz veins in most altered zones reveal increased Au grades where Au resides free [20 - 350 $\mu \mathrm{m}]$ in quartz vein material and within patches of heavily oxidized phases and arsenates including scorodite and beudantite.

Experimental: Samples were selected from high-grade drill core intervals at the Vertigo target and prepared as sample billets and polished thin sections. Thin section locations of interest were identified with petrography under reflected light (RL) using a Nikon Eclipse LV100POL microscope at the Earth and Planetary Materials Analysis facility at Western University. EDS and WDS analyses using a JEOL JXA-8530F hyperprobe field emission source electron microprobe at the Earth and Planetary Materials Analysis facility at Western University was performed on select areas of interest down to $1 \mu \mathrm{m}$ resolution to resolve elemental relationships. High resolution $(20 \mu \mathrm{m}) \mu \mathrm{XRF}$ element mapping on sample billets was completed using a Bruker M4 Tornado $\mu \mathrm{XRF}$ system equipped with a Rh X-ray source with an energy of $50 \mathrm{kV}$, a $12.5 \mathrm{~mm} \mathrm{Al} \mathrm{filter,} \mathrm{and} \mathrm{SDD.} \mu \mathrm{XRF}$ analysis of sample billets mapped the composition and element distribution of mineralized samples under vacuum to allow detection of light elements. 
Results: EPMA of thin section 1754402 shows that Au resides as coarse-grained electrum [10-20 $\mu \mathrm{m}]$ in quartz vein material and as grains within concentrically zoned beudantite, Figure 1. Complementary $\mu$ XRF element mapping of sample billet 1754363 displays overlapping Au and Ag element signals (electrum) that reside in $\mathrm{Si}$ (quartz) and $\mathrm{Fe}+\mathrm{Pb}+\mathrm{As}+\mathrm{S}$ (beudantite), Figure 2. SR-XRD data confirm best fit diffractogram peaks for beudantite and scorodite in sample 1754402, and beudantite for sample 1754363.

Discussion: Petrography, EPMA, $\mu \mathrm{XRF}$, and SR-XRD have been integrated to understand gold occurrence and associations with trace element distributions in a mineralogical, textural, and structural context. EPMA element spot analysis (EDS) and mapping (WDS), used with $\mu$ XRF element mapping and ancillary SR-XRD has resolved Au-Ag relationships in the most altered high-grade samples. Auenrichment manifests as native electrum that occurs in quartz veins and beudantite - a secondary lead iron arsenate sulfate hydroxide mineral occurring in the oxidized zones of polymetallic deposits [4]. Electrum is typically found in most altered and oxidized quartz vein samples associated with elevated Au grades and pathfinder element abundances. The presence of Au found with Ag as native electrum has implications for the solution complex responsible for Au and Ag transport. Since Ag is easily oxidized, when released into solution it is likely to have been transported in $\mathrm{C}^{-}$complex rather than in a reducing $\mathrm{HS}^{-}$(bisulphide) solution. Galena $(\mathrm{PbS})$, arsenopyrite (FeAsS), and pyrite $\left(\mathrm{FeS}_{2}\right)$ are the most common sulphides associated with Au mineralization. Enriched gold grades occur at shallow depths and it is likely that these sulphides were oxidized after deposition and generated acidic conditions [5]. Building on these findings, future investigation aims to describe the nature of the ore fluid responsible for Au enrichment.

Acknowledgments: Research described in this paper was performed at the APS and CLS. The APS is supported by the U.S. DOE under Contract No. DE-AC02-06CH11357 and the CLS. The CLS is supported by the CFI, NSERC, the U of S, the Government of Saskatchewan, Western Economic Diversification Canada, the NRC, and the CIHR. We thank Tina Hill, Gordon Osinski, Marc Beauchamp, Michel Fodje, Shaun Labiuk, and Wenqian Xu for their assistance with data collection and analysis. We gratefully acknowledge funding from NSERC and White Gold Corp.
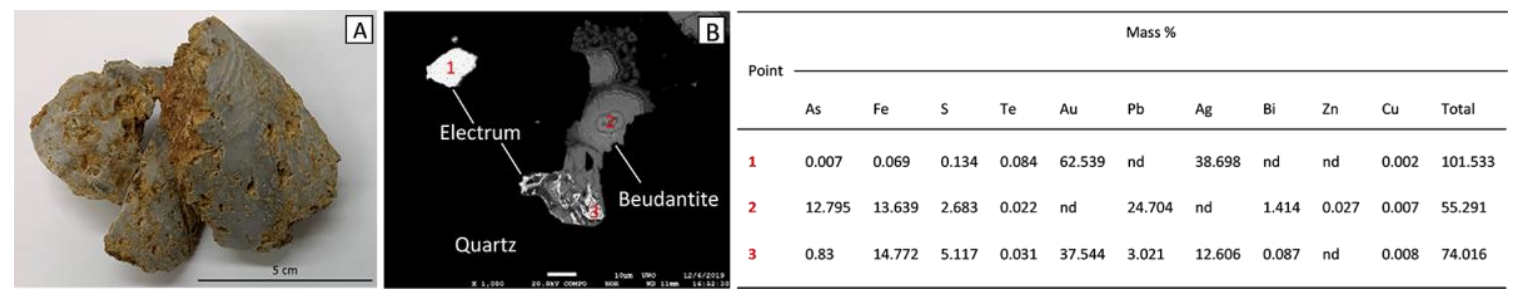

Figure 1. (A) Drill core for sample 1754402. (B) Electron probe microanalysis (EPMA) back-scattered electron image (BSE) of coarse, free electrum in quartz (1) and electrum within concentrically zoned beudantite (3). Wavelength dispersive spectroscopy (WDS) of selected points reveals mass \% measurement data for $\mathrm{Au}-\mathrm{Ag}$ ratios typical of electrum and $\mathrm{As}-\mathrm{Fe}-\mathrm{S}-\mathrm{Pb}$ ratios typical of beudantite. Peak fitting of powder SR-XRD data for the corresponding sample interval confirmed these mineralogical interpretations. 

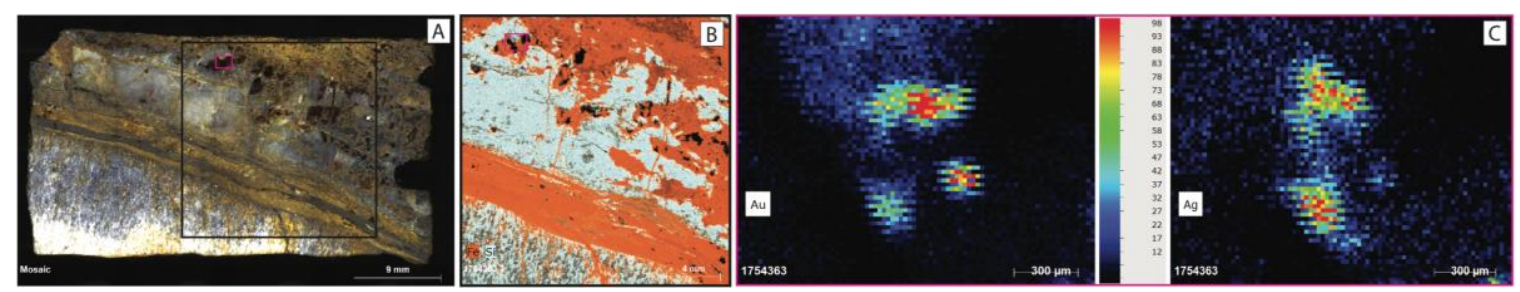

Figure 2. (A) Sample billet 1754363 cut from a composite drill core interval with Au and Ag grades of 94.2 and $246.0 \mathrm{~g} / \mathrm{t}$, respectively. The black rectangle is the area mapped using $\mu \mathrm{XRF}$ at $20 \mu \mathrm{m}$ resolution. (B) Bruker M4 Tornado $\mu$ XRF element map for Fe and Si. (C) Bruker M4 Tornado $\mu$ XRF element map for $\mathrm{Au}$ and $\mathrm{Ag}$, which occur as electrum in $\mathrm{Si}$ (quartz) and $\mathrm{As}-\mathrm{Fe}-\mathrm{S}-\mathrm{Pb}$ (beudantite).

\section{References}

[1] Allan, M. et al. (2013) "Magmatic and Metallogenic Framework of West-Central Yukon and Eastern Alaska," in Tectonics, Metallogeny, and Discovery: The North American Cordillera and Similar Accretionary Settings, pp. 111-168. doi: https://doi.org/10.5382/SP.17.04.

[2] Goldfarb, R. J. et al. (2000) “The Tintina Gold Belt - A global perspective," in Tucker, T. L. and Smith, M. T. (eds) The Tintina Gold Belt: Concepts, exploration, and discoveries: Special volume 2. Vancouver, BC: British Columbia and Yukon Chamber of Mines, pp. 5-34. Available at: http://pubs.er.usgs.gov/publication/70186627

[3] Alexander, J., Banerjee, N., \& Van Loon, L. (2020). Application of Synchrotron Radiation X-Ray Diffraction (SR-XRD) and Electron Probe Microanalysis to Understanding Gold Mineralization at the Vertigo Target, White Gold District, West-Central Yukon Territory, Canada. Microscopy and Microanalysis, 1-4. doi:10.1017/S1431927620016608

[4] Mindat.org (2021) Beudantite, Hudson Institute of Mineralogy. Available at: https://www.mindat.org/min-652.html\#autoanchor22 (Accessed: January 26, 2021).

[5] Singer, P. C. and Stumm, W. (1970) “Acidic Mine Drainage: The Rate-Determining Step," Science, 167(3921). doi: 10.1126/science.167.3921.1121. 